\title{
ADMINISTRATIVE AGENCIES AND THE SECURITIES AND EXCHANGE COMMISSION
}

\author{
WILLIAM L. CARY*
}

I

When he left the Securities and Exchange Commission (SEC) Mr. Justice Douglas suggested half seriously that every administrative agency should be dissolved at the end of ten years. None of us would accept this suggestion without qualification. Certainly I would disagree as to the SEC, with which I have been intimately associated. Yet the grain of plausibility in the statement, however over-dramatized it may be, is that occasional revitalization in every government agency is needed. Continuous administration of acts involving any industry can lead to channelized thinking, loss of excitement, and with it, loss of excited personnel. J. K. Galbraith ${ }^{1}$ has said that "Regulatory bodies, like the people who comprise them, have a marked life cycle. In youth they are vigorous, aggressive, evangelistic, and even intolerant. Later they mellow, and in old age-after a matter of ten or fifteen years-they become, with some exceptions, either an arm of the industry they are regulating or senile." I do not accept Galbraith's hyperbole any more than the opening statement. Following the ebb, there may again be a flow. In many ways regulatory agencies are no different from the federal departments of State, Treasury, Defense, or Justice. All of them have benefited from resurveys and changes of pace. Secretary McNamara's imaginative reshaping of the Defense Department is an example on a broad scale. I might say, however, that it would in my opinion be utterly impossible to achieve any real resuscitation with an annual rotating chairman as in the case of the Interstate Commerce Commission: someone has to be vested with responsibility.

Government regulatory agencies are stepchildren whose custody is contested by both Congress and the executive, but without very much affection from either one. Furthermore, as stepchildren they are often starvelings, receiving only the crumbs in the federal budget. Despite these difficulties, the SEC has always had a reputation for service and responsibility and a reserve of high quality staff members. Like other institutions it has had its ups and downs, with meager budgets following the war. (And the importance of an adequate budget is self-evident.) While the Commission sought to maintain its standard of competency, it scarcely had time to see the direction in which the industry that it regulated had been changing. Without additional personnel and without fiscal support, the only choice was to meet

- Chairman, Securities and Exchange Commission; Professor of Law, Columbia University (on leave).

This paper represents my personal views, not those of the Commission. Credit, if any, for the events described must be shared with my valued colleagues-but responsibility for their interpretation is entirely mine.

${ }^{2}$ Jomn K. Galbraith, The Great Crash ijt (1955). 
the day-to-day grist of tough financial problems on an ad hoc basis. At times in the course of administrations whether Democratic or Republican, the only-indeed the highest-goal expected of any agency seems to be that it conduct its day-to-day work honestly and thoroughly without getting into any trouble. In a political world even that may be high praise, but it offers to the agency only a dusty road for its horizon.

For the SEC, as for most other institutions, an occasional re-examination is needed. At the same time we have to recognize that taking the new road is riskier, but also more fruitful. It should be easy to be both honest and conscientious, and I do not underestimate the significance of progress through accretion-in the spirit of the common law. But that is not enough. John W. Gardner recently said that "a society that has learned the secret of continuous renewal will be a more interesting and a more vital society. ..."2 The real fear that should haunt all administrative agencies is that of inertia, the loss of initiative. How can this be surmounted?

In rethinking the problems of the SEC, one example was already available in Ig6I-Ig62. A successful approach was already being taken in the Federal Communications Commission (FCC). The television industry was awakened. Several major FCC bills ${ }^{3}$ were passed, and any legislative success in Congress was arduous during the Kennedy Administration. Why not, therefore, like Newton Minow, start off by comparing conditions in the securities industry with the vast wasteland of TV programs? ? $^{4}$ The answer was several-fold. First of all, Mr. Minow was operating with commissioners originally unsympathetic with change or at least the changes he proposed. He had to speak out dramatically, courageously and alone, or not at all. He could speak, not act. Secondly, the FCC has relatively limited powers in the vital area of programming; the SEC, on the other hand, has rather broad and general powers-which it had not adequately exercised. Thirdly, a broadside against the TV industry would not have the same effect, psychological or otherwise, as one addressed to an industry so closely tied with the stock market. Such an attack upon the latter was not warranted; ${ }^{\circ}$ but even if it were, it might have been disastrous in its market impact, and therefore irresponsible. Under these circum-

${ }^{2}$ Gardner, Renewal in Societies and Men, in I962 Carnegie Corp. ANN. Rep. 3.

${ }^{3} 75$ Stat. 420 (196r), 47 U.S.C. $\$ \$ 155,405,409$ (Supp. IV, I963) (delegation and rcorganization amendments); 76 Stat. 64 (I962), 47 U.S.C. $\$ \$ 390-97$ (Supp. IV, I963) (matching grants for educational TV); 76 Stat. I50 ( 1962 ), 47 U.S.C. $\$ \$ 303,330$ (Supp. IV, r963) (authority to requirc allchannel receivers); 76 Stat. 419 (1962), 47 U.S.C. $\$ \$ 70 \mathrm{r}-44$ (Supp. IV, 1963 ) (Communications Satellite Act).

N.Y. Times, May ro, I961, p. I, col. 2.

- The letter of transmittal to Congress which accompanied the Commission's Report of Special Study of Securities Markets of the Securities and Exchange Commission made clear that, while serious shortcomings were apparent, the fundamental structure of the securities markets and the regulatory pattern of the securities acts did not require drastic reconstruction. Securities and Exchange Commission, Report of Special Study of Securities Markets, H.R. Doc. No. 95, 88th Cong., Ist Sess., pt. I, at iii (I963) [hereinafter referred to as Special Study]. 
stances, it was necessary to take a totally different tack toward raising standards and shifting direction in the securities industry. Lawyers prefer if possible to take positions on the basis of thorough, fair, and responsible study. It is slower, but any major and abiding shift in thinking within the government is a laborious process at best.

A. The first step in the case of the SEC was to bring in some consultants who were both knowledgeable and could afford to take some time off to make recommendations. They were two lawyers (one a professor) and a businessman. The businessman was to insure that there was no waste of manpower observable, and the lawyers were there to inquire where we were going in the administration of the laws under our supervision.

One question was whether any SEC functions should be scrapped. This is a novel inquiry among government institutions, flying in the very face of Parkinson's Law. ${ }^{8}$ In this connection an analysis was made of an area of regulation which had oncefrom $193^{8}$ to 1945 -been our largest and most successful achievement-the Public Utility Holding Company Act. ${ }^{7}$ Now that it had fulfilled its basic purposes-the rationalization of an industry-should it be dropped entirely as functus officio? Or if the Public Utility Holding Company Act should not be jettisoned entirely, should its administration be shifted to the Federal Power Commission (FPC), which is charged generally with the regulation of the gas and electric industries? This, we found, was not a matter of logic alone. It was a political question. Many people who before have inveighed against the SEC in its administration of the act prefer a known to an unknown agency, the FPC. The latter could undoubtedly strengthen its hold over the gas and electric utilities if SEC financing powers were coupled with its existing jurisdiction over routes and rates. Opposition to any change began to develop. The question, therefore, was left whether we ought to tamper with the Utility Act. Is it worth one's while to devote his energies to ridding an agency of its vestigial duties? It is almost as hard to wipe a statute off the books as it is to enact one, and much less rewarding. More important constructive legislation was needed, and Congress has only limited time for agencies such as the SEC. Therefore, since the Public Utility Holding Company Act inhibits the rebirth of certain abuses, it seemed of value to retain on the books under our aegis-but with a limited amount of regulatory activity. By its very existence, it is a policeman even without aggressive enforcement.

B. The overwhelmingly predominant phase of our re-examination was the Special Study of the Securities Markets authorized by Congress in I96I and completed on August 8, 1963 . To appreciate the motivation of the congressional resolution authorizing the Study, the condition of the securities markets during I96r must be appreciated. 8 This was a turbulent market in which a record number of companies, many of them highly speculative, were going to the public for financing.

${ }^{\circ}$ Cyril N. Parkinson, Parkinson's Law (1957).

${ }^{7}$ Public Utility Holding Company Act of 1935,49 Stat. 803 , I5 U.S.C. $\$ \S 79 a-79 z(6)$ (1958).

${ }^{8}$ See Cary, The Special Study of Securrities Markets of the Securities and Exchange Commission, 62 Mich. L. REv. 557, 558 ( 1964$)$. 
The "hot issue" was prevalent; initial trading markets for many new issues reflected an extravagant premium over the offering price. Price-earnings ratios were at extraordinary levels. Trading volume was soaring, accompanied by noticeably high "fails" to receive or deliver stock certificates. The Commission's enforcement machinery was overloaded. Criminal references to the Department of Justice and administrative proceedings against brokers were at all time highs. The most dramatic breakdown in controls was reflected in the SEC investigation of the American Stock Exchange, ${ }^{9}$ prompted by the Commission's expulsion of the leading specialist firm of Re, Re \& Sagarese..$^{10}$

The Commission, the self-regulatory agencies, and the industry were overwhelmed with daily administrative problems and were forced to meet issues on an ad hoc basis. Thus, it seemed a highly propitious time for a thorough survey of the state of the securities markets and the adequacy of investor protection. Without money and personnel, such an ambitious program would not be possible.

Here in retrospect we were beneficiaries of the wisdom of Congress and an element of luck. The question might have been posed whether the Study should be made by the Congress or by the SEC. Congressional investigations of regulatory agencies are, on balance, undoubtedly salutary. Indeed, they may well be the factor most responsible for keeping agencies from falling asleep, or suffering the fate envisioned by Galbraith. It may also be highly appropriate for Congress to investigate matters which raise novel or broad policy issues or where no other agency with the requisite expertise is available. The Senate hearings which laid the foundations for the Securities Act of $1933^{11}$ and the Securities Exchange Act of $1934^{12}$ were undoubtedly of this type. ${ }^{13}$ But the question always arises whether a study could be done differently or better. A congressional investigation might have had the tendency of focusing on the SEC rather than upon major developments in the market. Not infrequently general policy inquiries are clouded and confused by examination into particular cases, often stemming from private complaints. The Commission might then have spent most of its time attempting to defend what it had or had not done within the limitations of a straitened budget. Thus the real object might well have been missed, for we, like the securities industry itself, had been so engrossed that

\footnotetext{
- SEC Staff Report on Organization, Management and Regulation of Conduct of Members of the AMerican Stock Exchange (1962).

${ }^{10} \mathrm{Re}$, Re \& Sagarese, SEC Securities Exchange Act Release No. 6551, May 4, x961; SEC Securitics Fxchange Act Release No. 6900, Sept. 21, 1962.

${ }^{11} 48$ Stat. 74 (1933), as amended, 15 U.S.C. $\$ \$ 77^{2}$ to aa (1958), as amended, 15 U.S.C. $\$ \$ 77 b-h$ (Supp. IV, 1963).

1248 Stat. $88 \mathrm{I}$ (1934), as amended, I5 U.S.C. $\$ \$ 78$ a to hh-I (1958), as amended, 15 U.S.C. $\$ 578 \mathrm{c}(\mathrm{a})-\mathrm{s}$ (Supp. IV, 1963).

${ }^{13}$ According to Hillel Black, The Watchdogs of Wall Street ro (1962), the Senate Hearings originated in a Republican desire to thwart a Democratic scheme. In 1932 Frederick C. Walcott, Republican Senator from Connecticut, believed that Democratic Wall Street traders might launch a bcar raid to depress the market and discredit the Hoover Administration. Public hearings intended to expose this plan failed of their immediate object, but they did uncover enough evidence of pools, commercial bribery, and manipulation to stimulate further hearings in 1933 and 1934.
} 
there was neither time nor personnel nor opportunity to back away and ask where the industry was moving and whether present regulations met the changes wrought over thirty years.

On August 24, I96I, Congressman Peter Mack introduced a resolution (now section $\mathrm{Ig}(\mathrm{d})$ of the Securities Exchange Act) authorizing and directing the Commission "to make a study and investigation of the adequacy for the protection of the investors, of the rules of the ... exchanges and the national securities associations. . .."14 The Mack resolution provided a vehicle for re-examination by the Commission. Naturally, therefore, we seized upon it as the opportunity for which we were seeking. We said before the House Subcommittee: ${ }^{15}$

Our present budget ... and our manpower, will not support a thorough study of the exchanges and over-the-counter markets at this time. ... [T] [ constant danger in our Commission is that with market activities and flotations at an all time high, we become so overwhelmed with immediate problems ... that we are virtually forced to concentrate all our funds and manpower upon them and cannot do any long-range planning.

As already noted, the Study of some 3,000 pages was submitted to Congress in the late summer of Ig $_{6}$. Its breadth may perhaps be appreciated by a notation of the range of its subject matter: qualification standards for those in the securities industry; ${ }^{16}$ selling and investment advisory practices; $;^{17}$ distributions of securities, including problems of "hot issues"; ${ }^{18}$ intrastate and real estate offerings; ${ }^{18}$ the operation of the various securities markets, such as the New York Stock Exchange, ${ }^{20}$ the regional exchanges, ${ }^{21}$ the "third market"22 (i.e., the trading of listed securities off the exchanges), and the over-the-counter market, ${ }^{23}$ and the interrelationship of these markets; the obligations of issuers of both listed and unlisted publicly held securities; ${ }^{24}$ the gaps and inconsistencies in securities credit regulation; ${ }^{25}$ selected aspects of mutual funds; $;^{26}$ and the operation of self-regulation. ${ }^{27}$

Substantial progress has since been made. The Study has given rise to a bill ${ }^{28}$ now already through the Senate and before the House, and to a number of rulemaking proceedings to exercise power which the Commission already has. Fur-

It H.R.J. Res. 438, 87th Cong., Ist Sess. (I96I), which became law, 75 Stat. 465 (I96r), as I9(d) of the Securities Exchange Act of 1934, 48 Stat. 88I (1934), I5 U.S.C. $\$ 78 \mathrm{a}$ to hh-1 (I958), as amended, 15 U.S.C. $\$ 78$ (s)(d) (Supp. IV, 1963).

${ }^{15}$ Hearings on H.R.J. Res. 438 Before a Subcommittee of the House Committee on Interstate and Foreign Commerce, 87 th Cong., Ist Sess., vol. 3 , at 8 (196r).

${ }^{10}$ Special Study, pt. I, ch. II.

${ }^{17}$ ld., pt. I, ch. III.

${ }^{28}$ Id., pt. I, ch. IV.B.3.

${ }^{10} I d$, pt. I, ch. IV.D.-E.

so Id., pt. 2, ch. VI.

${ }^{21}$ Id., pt. 2, ch. VIII.E.

20 Id., pt. 2, ch. VIII.D.

${ }^{23}$ Id., pt. 2, ch. VII.

st Id., pt. 3, ch. IX.

${ }^{25}$ Id., pt. 4, ch. X.

${ }^{20}$ Id., pt. 4, ch. XI.

${ }^{27}$ Id., pt. 4, ch. XII.

${ }^{28}$ S. 1642 , H.R. 6789, H.R. 6793, 88th Cong., Ist Sess. (1963). 
thermore, the industry has already made substantial progress in improving itself. As soon as the Commission began asking questions, the industry became aware of evident deficiencies. Indeed it might be said to have made its own special study. Our criticism has not been met with enthusiasm, but a constructive attitude rather than total antagonism has been preserved-thanks in part to a sustained effort made to maintain thoroughness, fairness, and responsibility. As the London Economist said of the Study: "Americans who have long admired the quality of investigations conducted by the British Royal Commission may take heart. It can happen here."20

Perhaps another reason why a study of this type can have an impact upon both the Commission and the industry it regulates is that there was a conscious decision to give the study group considerable independence. It would have been impossible to secure complete agreement of all five commissioners on a 3,000 page analysis within the limited time period which we were allowed. It is obvious, moreover, that objective views can provide a new and welcome stimulus to us on the inside. Sensitive to congressional criticism, we all tend to justify every action rather than admit human (and-even more-institutional) fallibility.

Furthermore, the Commission would be required to act subsequently on the recommendations of the Report of the Special Study under the Administrative Procedure Act; and if a firm and hardened position were taken by the Commission rather than by an independent group, it would be difficult if not impossible for us to deal with the industry. Finally, it was anticipated that while the report would focus on the shortcomings in the industry and in the self-regulatory agencies, in certain respects there would be express or implied criticism of the Commission itself. Institutions-government, quasi-government or private-all benefit from examination. ${ }^{30}$ A spirit of independence provides the additional advantage of staff enthusiasm and esprit de corps, coupled with a fresh point of view.

Such a pattern might well be applicable to other administrative agencies. On the one hand, it is desirable to introduce outsiders. In our case, the Special Study was staffed by many lawyers from private practice, economists, and university professors. On the other hand, it must not be wholly divorced from those who will have the responsibility of running the agency. There were a number from the Commission's regular staff to provide some continuity between the two stages, making recommendations and putting them into effect.

C. Another phase of the re-examination concentrated on the Investment Company Act of $1940 .{ }^{31}$ It had its genesis more than six years ago, in 1958 . The industry has gone through dynamic changes, and there is some question whether the act has the plasticity to meet them. Until recently the Commission's administration of

${ }^{20} 208$ LONDON ECONOMIST 587 (1963).

${ }^{80}$ I would emphasize, however, the Commission did not divoree itself from the Special Study but strongly endorsed its soundness and expressed the conviction that it was a thoroughly responsible document. Special Study, pt. I, at iv-v.

${ }^{31} 54$ Stat. 789 (1940), as amended, I5 U.S.C. $5580 a-1$ to -52 (1958), as amended, $\times 5$ U.S.C. $\$ 580 a-2(a)(37)$ to -39 (a) (Supp. IV, 1963). 
the Investment Company Act was largely focused on disclosure requirements, occasional enforcement of regulatory provisions, and many intellectually difficult problems involving exemptions.

Only in the late fifties did the Commission fully appreciate that this was no longer a modest industry whose relative insignificance in comparison with other investment media had tended to obscure basic questions warranting thorough examination. Lately the industry had become a major alternative among investors' choices. Investment companies have grown from 2.5 billion dollars in I940 to over 23 billion in 1960 and 36 billion in $1963 .{ }^{32}$ Shareholder accounts of mutual funds were 296 thousand in $1940,4.9$ million in 1960 , and over 6 million in $1963 .^{33}$ Furthermore, administration of the act could no longer be confined to the traditional investment company alone. Other financial institutions developed means to take advantage of the mutual fund concept which was attracting public funds-first the insurance companies with variable annuities, and now the banks with variations of their traditional common trust funds. In consequence, a new approach was sought upon which to base regulation of both the variable annuities of insurance companies and the commingled accounts of banks, without impinging on the traditional jurisdiction of insurance or banking regulatory authorities. Our position was that these institutions are moving squarely into the mutual fund business, and hence that all investors in mutual funds should receive the same protections-regardless of whether the fund is sponsored by a bank, ${ }^{34}$ an insurance company, ${ }^{35}$ a broker, an investment counsellor, or any other person.

Again, as a fresh approach both to the understanding by investment companies of the basic requirements of the I940 Act and to its more effective enforcement, we have developed a new comprehensive annual report form to be certified by the fund's independent certified public accountant. ${ }^{36}$ This represents a move toward self-inspection which is consistent with a philosophy that part of the regulatory responsibility should be placed upon the industry. There is no reason why government should expand when others can be induced to fill the vacuum. ${ }^{37}$

In an attempt to resolve the structural problems inherent in the investment company industry, we were fortunate in having already underway, since 1958 , a study of mutual funds prepared for the Commission by the Wharton School of Finance

${ }^{39}$ SEC, Classification, Assets and Taxation of Registered Investment Companies under the 1940 ACT AS OP JUNE 30,1963 .

3a ATthur Wiesenberger, INVESTMENT COMPANIES 28 (1963).

34 Letter to Senator A. Willis Robertson, I Io Cong. REC. 791-92 (daily ed. Jan. 22, 1964); Hearing on Common Trust Funds Before a Subcommittee of the House Committee on Government Operations, 88th Cong., Ist Sess. 3 (1963).

${ }^{25}$ Securities and Exchange Comm'n v. Variable Annuity Life Ins. Co., 359 U.S. 65 (1959); The Prudential Insurance Company of America, SEC Investment Co. Act Release No. 3620, J2n. 22, 1963, affd, Prudential Ins. Co. v. SEC, 326 F.2d 383 ( 3 d Cir. 1964).

${ }^{30}$ Address by William L. Cary, "The Securities and Exchange Commission After the Special Study of Securities Markets," Investment Bankers Association of America, Dec. 2, I963. An "Exposure Draft" of a proposed revision of Annual Report Form N-30A-r for Maniagement Investment Companies was circulated to members of the industry in March, 1964.

${ }^{37}$ Cary, Self-Regulation in the Securities Industry, 49 A.B.A.J. 244 (Ig63). 
and Commerce. ${ }^{38}$ This has been supplemented, particularly as to the selling area, by work of the Special Study, ${ }^{39}$ and, as to the industry structure, by extensive case studies by a group brought especially to the Commission and operating within our permanent staff. We have examined the highly competitive drive to sell mutual funds and the devices used for that purpose-such as contractual or frontend load plans. ${ }^{40}$ In many instances these plans involve a commission of fifty per cent of the first year's payment, which may be lost if the contract lapses. Without our taking direct action against the front-end load (which would probably require statutory amendment), the very study of the field has resulted in a trend to voluntary reduction of its impact by lessening and stretching out the load. ${ }^{41}$

Through our studies, also, we have come to identify the consequences of conflicts of interest fostered by the nature of the industry structure, and tolerated within the act. In analyzing investment companies we have found a number of potential or actual problems which are inherent in the present pattern of the industry. Many of them stem from a unique historical development, for the management of investment funds has been primarily by contract with outsiders rather than by employees of the company itself. In part as a result of our activities and in part because of some sixty odd lawsuits brought by complaining shareholders, there is some evidence that the fund directors are now increasingly aware of their responsibility and are assuming more active and vigorous roles. However, in arriving at any totally satisfactory solution, progress has been retarded by traditional patterns in the industry.

D. Another area for restudy still presents itself to the Commission during the coming year. It is the field of disclosure, involving the registration statements and proxy statements, in which the Commission has done a thorough job and developed a commendable tradition. The Report indicated that "the Commission's administration of the registration provisions of the Securities Act has been one of its most outstanding achievements and the statute itself has proved generally adequate and workable." A2 At the same time it pointed out limited areas in which improvements could be made. For example, much more can be done in informing the bar and the public of our policies and practices in the disclosure area, and in removing the mystique surrounding the registration process. Furthermore, on a longer-term basis, efforts should be made to achieve a greater integration as to information required under the Securities Act of 1933 and the Securities Exchange Act of $1934 .{ }^{43}$

${ }^{38}$ A Study of Mutsal Funds, H.R. REP. No. 22\%4, 87th Cong., 2d Sess. (1962).

${ }^{30}$ Special Study, pt. 4, ch. XI.

.10 Id. at' 172 .

${ }^{21}$ Registration Statement No. 2-15015, Variable Annuity Life Ins. Co., post effective amendment filed with SEC April $7, x 964$.

12 Special Study, pt. I, at 557 .

${ }^{13}$ A critical analysis of the Special Study proposal to secure greater integration as to information required under the Securities Act of 1933 and the Securities Exchange Act of 1934 appears in Heller, "Integration" of the Dissemination of Information Under the Securities Act of 1933 and the Securities Exchange Act of 1934, this symposium, 29 LAw \& CoNTEMP. Pros. 749 (1964). 
Certainly prospectuses could also be improved, as could the proxy rules. A beginning to remove the barnacles found to have developed over thirty years of administration is already being made, but it will of necessity take time. This is a more technical area for selected improvement, but a rewarding one with which the bar and the industry should be in total sympathy.

\section{III}

Hand in hand with the effort of re-examination was the effort of getting and keeping good people. It is impossible to make headway without the efforts of a devoted staff combined with independent views from the outside. This problempersonnel-is an ever present one in government, particularly when the agency is not attempting to move ahead but simply to carry on its day-to-day responsibilities. As already indicated, the Commission has had a reserve of excellent, able, and dedicated public servants. Yet when I came to the SEC, I was told by people on the staff not to try to get any new top-ranking law graduates and young lawyers, first because we could not attract them, and secondly because they would leave. These are premises with which I totally disagree. We strove to demonstrate the error of the first point-to bring again to the Commission the reputation it enjoyed in the 1930s, when almost every young lawyer in the government wanted to be associaated with the SEC or the Solicitor General's office-as the two best law offices in Washington. In this effort we have had some success. We also found by statistical analysis that superior lawyers generally leave the SEC no sooner and no later than average ones. Much depends on whether their efforts are recognized and their talents fully challenged. Happily, our long tradition of intellectual insubordination (encouraging every one to speak his mind) has continued to flourish, and this in turn has kindled excitement in the work. It is often wanting in government institutions.

It must be recognized that the personnel problem is in part a function of the budget, as reflected in salaries, promotions, and the opportunity to bring in new and able young people-particularly lawyers. Here again, the effort to introduce new thinking may in turn generate encouragement from the Bureau of the Budget and from Congress. To some extent there is a circular effect: a larger budget enables an agency to look ahead of its day-to-day responsibilities, while if it looks ahead, Congress and the executive may find a basis for making more funds available. In this respect the Commission has had good fortune with an increase in budget over four years from $\$ 9.5$ million for $196 \mathrm{I}$ to $\$ 14.6$ million (estimate) for 1965 , and in personnel from $x, 095$ to $x, 480$ (estimate). ${ }^{44}$ The move to expand-within limits-is, I trust, to be differentiated from "empire building": a common hallmark of business as well as government administration. We have not been interested in growth as such. Indeed we have firmly declined suggestions by members of Congress that we

"House Comm. on Appropriations, Independent Offices Appropriation Bill, 1965, H.R. REP. No. $\mathrm{x}_{4} \mathrm{I} 3$, 88th Cong., 2d Sess. 16 (1964). 
undertake new tasks not directly related to securities regulation, and we should be prepared to contract if our work should ever decline.

After all of these efforts in the direction of re-examination and change, some have asked whether it was not time for us to consolidate and look for no more avenues for innovation. This may well be true in part. After all, Mr. Gardner's thesis of "continuous renewal" assumes the careful execution as well as the creation of ideas. There remains much to be done to carry out the recommendations which have already been made. This is our present task, and it is a large one. With such a program ahead, we must remain aware that progress in government is exasperating and laborious, but it need not be impossible. This is not the time for honest, conscientious administration alone-without momentum. 